\title{
Penerapan Konsep User Experience (UX) Pada Perancangan Dashboard Profil Mahasiswa Baru Universitas Negeri Jakarta
}

\author{
Hamidillah Ajie', Muhammad Zulfikar², Vina Oktaviani ${ }^{3}$ \\ 1,2,3 Pendidikan Teknik Informatika dan Komputer Fakultas Teknik \\ Universitas Negeri Jakarta \\ 1hamidillah@unj.ac.id, ${ }^{2}$ fikaraza.muhammad@gmail.com, ${ }^{3}$ vinaoktaviani@unj.ac.id
}

\begin{abstract}
Abstrak
Pengolahan data penerimaan mahasiswa baru jenjang Strata 1 dan Diploma 3 di Universitas Negeri Jakarta (UNJ) belum didukung oleh sistem informasi. Hal tersebut menimbulkan beberapa masalah seperti sulitnya mendapatkan informasi untuk bahan evaluasi akreditasi, pemaparan profil program studi, penentuan daya tampung, prediksi penerimaan mahasiswa baru, dan rekapitulasi data mahasiswa baru. Tujuan penelitian ini adalah untuk merancang sebuah dashboard yang dapat menyajikan visualisasi data penerimaan mahasiswa baru dalam bentuk grafik yang sederhana dan menarik. Perancangan dashboard menggunakan konsep User Experience untuk mengembangkan dashboard yang nyaman dan mudah digunakan oleh pengguna. Perancangan dashboard dibuat sampai pada tahap evaluasi dengan mengukur usability dari dashboard kepada calon pengguna. Pengujian usability dilakukan kepada pimpinan dan stakeholder UNJ sebanyak 35 orang. Pengujian usability meliputi tiga hal, yaitu efektivitas, efisiensi, dan kepuasan. Hasil menunjukkan bahwa dari segi efektivitas sebagian besar task berada diatas rata-rata completion rate, dari segi efisiensi memiliki waktu pemakaian produk yang cukup baik pada sebagian besar task dan dari segi kepuasan menunjukkan hasil baik dan sangat baik. Berdasarkan hasil pengujian usability, maka dashboard dapat dikembangkan lebih lanjut untuk digunakan oleh pimpinan maupun stakeholder UNJ.
\end{abstract}

Kata kunci : Dashboard, Profil, Mahasiswa Baru, User Experience, Usability.

\section{Pendahuluan}

Kebutuhan informasi berkembang pesat karena banyaknya data yang akan diolah menjadi sebuah informasi untuk digunakan sebagai bahan perancangan kegiatan dan pengambilan keputusan pada sebuah organisasi. Hal ini membuat berbagai sistem makin banyak dikembangkan untuk mendukung dan mempermudah pekerjaan manusia. Perkembangan teknologi informasi saat ini memungkinkan manusia mengembangkan suatu sistem yang berfungsi untuk mengolah data menjadi informasi sesuai dengan kebutuhannya masingmasing. Sistem ini yang kemudian dikenal dengan Sistem Informasi.

Sistem informasi pada dasarnya mengolah data menjadi informasi yang memiliki nilai bagi penerimanya. Makin banyak data yang diolah maka informasi yang dihasilkan juga akan makin banyak. Dari banyaknya informasi yang diperoleh, maka sebuah organisasi dapat melakukan pengambilan keputusan yang tepat. Keputusan yang tepat dapat diambil apabila informasi yang disajikan memiliki visualisasi data yang baik dan sederhana. Salah satu sistem yang dapat menampilkan data dalam bentuk visualisasi data yang baik dan sederhana adalah dashboard.

Dashboard dengan layar yang didesain dengan baik, yang memonitor aspek bisnis yang menjadi tanggung jawab pelaku bisnis dan memungkinkan para manajer dengan cepat mengidentifikasi masalah dan menentukan langkah perbaikan untuk meningkatkan kinerja organisasi (Rasmussen, dkk., 2010: 6). Berdasarkan Ramussen, dashboard digunakan oleh pelaku bisnis untuk memonitor perusahaan yang dipimpin dan mengambil keputusan dari informasi yang ada. Dashboard menjadi salah satu cakupan dari Business Intelligent (BI) sebagai representasi penyajian data dalam bentuk informasi yang lebih sederhana meliputi bagan yang canggih, ukuran, indikator, tabel, scorecards, dan peta strategi. Pada saat ini dashboard banyak digunakan dalam berbagai bidang tertentu untuk memonitor kinerja dan menyajikan informasi yang dibutuhkan sebagai bahan dalam pengambilan keputusan. Seperti dalam lembaga pemerintahan, lembaga kesehatan dan lembaga pendidikan.

Universitas Negeri Jakarta (UNJ) adalah salah satu lembaga pendidikan yang dalam menjalankan aktivitasnya telah memanfaatkan beberapa sistem informasi berbasis web, seperti: Situs Portal UNJ (www.unj.ac.id), Sistem Informasi Akademik (siakad.unj.ac.id), Sistem Informasi Uang Kuliah Tunggal (siukat.unj.ac.id), Sistem Informasi Penerimaan Mahasiswa Baru (penmaba.unj.ac.id) dan situs dari lembaga-lembaga yang terdapat di UNJ. 
Berdasarkan beberapa sistem informasi yang dimiliki UNJ, aktivitas diberbagai kegiatan UNJ belum sepenuhnya didukung oleh sistem informasi yang ada. Salah satunya dalam hal pengolahan data mahasiswa baru. Pengolahan data mahasiswa baru dapat digunakan sebagai informasi profil mahasiswa baru UNJ. Proses penerimaan mahasiswa baru yang dilakukan setiap tahun, belum memiliki sebuah sistem informasi yang mengolah data pendaftar seleksi (peminat), data mahasiswa baru yang diterima, data sebaran wilayah asal mahasiswa baru dan data pendukung lainnya menjadi bentuk visualisasi data yang baik dan sederhana.

Data penerimaan mahasiswa baru UNJ memiliki fungsi antara lain sebagai rekapitulasi data historik, prediksi penerimaan mahasiswa baru pada tahun berikutnya, pemaparan profil program studi, penentuan daya tampung, bahan evaluasi akreditasi universitas ataupun program studi, dan profil mahasiswa baru bagi masyarakat umum. Data penerimaan mahasiswa baru UNJ belum terintegrasi dengan baik, hal ini disebabkan oleh proses seleksi dikelola lembaga yang berbeda sesuai dengan jalur seleksi yang diadakan.

Pada saat masa penerimaan mahasiswa baru jenjang Strata 1 (S1) dan Diploma 3 (D3), UNJ menerima mahasiswa baru dari beberapa jalur seleksi, yaitu: Seleksi Nasional Perguruan Tinggi Negeri (SNMPTN), Seleksi Bersama Masuk Perguruan Tinggi Negeri (SBMPTN), dan jalur mandiri (Penmaba). Pengadaan jalur SNMPTN dan SBMPTN berada di bawah koordinasi Direktorat Jenderal Pendidikan Tinggi (Dirjen Dikti), sedangkan jalur mandiri diadakan oleh UNJ yang disebut jalur Penmaba. Setiap tahunnya jalur seleksi mahasiswa baru juga dapat mengalami perubahan kebijakan. Contohnya pada tahun ajaran 2015/2016 Fakultas Teknik masih menerima mahasiswa baru Alih Program melalui jalur Penmaba dan pada tahun ajaran 2016/2017 tidak menerima mahasiswa baru Alih Program. Contoh lainnya, pada tahun ajaran 2017/2018 terdapat Fakultas baru yang merupakan hasil pengembangan dari Fakultas Ilmu Pendidikan.

Masa penerimaan mahasiswa baru yang diadakan setiap tahunnya akan menghasilkan sejumlah data berupa peminat, mahasiswa baru yang diterima, sebaran wilayah asal mahasiswa baru, sebaran berdasar kelas wilayah asal, jenis asal sekolah, jenis kelamin, agama, dan sebaran golongan Uang Kuliah Tunggal (UKT) mahasiswa baru. Data ini dapat diolah menjadi sejumlah informasi yang dapat dimanfaatkan untuk melakukan pengamatan, analisis, rekapitulasi, prediksi penerimaan mahasiswa baru, pemaparan profil program studi, penentuan daya tampung, ataupun digunakan sebagai bahan evaluasi pada saat akan melakukan akreditasi. Oleh karena itu diperlukan sebuah sistem informasi yang mengolah data mahasiswa baru dan menyajikannya secara ringkas serta berkala.
Salah satu solusi untuk menyajikan data dalam bentuk informasi visual yang sederhana dan menarik adalah dashboard profil mahasiswa baru UNJ. Dalam proses pengembangannya diperlukan desain antarmuka yang dapat memberikan kemudahan, kenyamanan, dan efisiensi dalam penggunaan aplikasi tersebut. Salah satunya dibutuhkan konsep perancangan yang tepat dan matang agar aplikasi yang dibuat dapat digunakan secara maksimal.

Konsep perancangan aplikasi yang baik, tentunya dapat melibatkan semua aspek. Konsep tersebut juga dapat berjalan secara kontinuitas, yang artinya akan ada perbaikan atau evaluasi secara bertahap terhadap aplikasi yang dibuat sehingga aplikasi dapat berjalan maksimal. Salah satu konsep yang fokus pada rancangan desain dari awal sampai akhir pada suatu produk aplikasi, yaitu: User Experience (UX). Menurut Marsh (2015:5) mendesain dengan menggunakan konsep UX, hampir sama prosesnya seperti melakukan penelitian ilmiah, yaitu: melakukan riset, mengembangkan ide untuk mengatasi kebutuhan user, dan juga kebutuhan yang diperlukan dalam suatu produk, serta membangun dan mengukur solusi tersebut di dunia nyata untuk melihat apakah solusi tersebut dapat berjalan.

Dengan menggunakan UX, diharapkan aplikasi yang dibuat dapat meningkatkan interaksi user dengan aplikasi yang dibuat dari segi kemudahan, kenyamanan, dan efisiensi. Namun, melihat banyaknya user yang akan terlibat berdasarkan karakteristik yang berbeda-beda, maka diperlukan studi lanjut mengenai UX terhadap dashboard yang akan dikembangkan. Berdasarkan permasalahan yang ada, maka penulis membuat penelitian dengan judul "Penerapan Konsep User Experience (UX) pada Dashboard Profil Mahasiswa Baru Universitas Negeri Jakarta”.

\section{Dasar Teori}

\subsection{Profil Mahasiswa Baru Universitas Negeri Jakarta}

Profil adalah pandangan, lukisan (gambar), sketsa biografis, penampang, grafik atau ikhtisar yang memberikan fakta tentang hal-hal khusus (Kamus Besar Bahasa Indonesia).

Mahasiswa baru adalah peserta seleksi penerimaan mahasiswa baru yang telah dinyatakan diterima di universitas, institut atau akademi, yang masuk dari berbagai jalur penerimaan seleksi mahasiswa baru seperti Seleksi Nasional Masuk Perguruan Tinggi Negeri (SNMPTN), Seleksi Bersama Masuk Perguruan Tinggi Negeri (SBMPTN) dan berbagai jalur masuk lainnya baik yang diselenggarakan secara nasional maupun secara lokal oleh universitas negeri maupun swasta (Muchsin, 2016: 1).

Kesimpulan yang dapat diambil dari teori profil dan mahasiswa baru yang telah diungkapkan bahwa profil mahasiswa baru adalah pandangan atau gambaran peserta didik di tahun pertama pada 
institusi perguruan tinggi mengenai fakta tentang halhal khusus.

\subsection{Desain User Experience (UX)}

Desain UX adalah disiplin ilmu yang berfokus pada mendesain experience dari awal sampai akhir produk tertentu. Mendesain experience adalah merencanakan dan bertindak dari serangkaian perintah yang harus dilaksanakan. Dimana hasil dari merencanakan dan kegiatan tersebut harus menghasilkan perubahan perilaku pada grup sasaran. Grup sasaran yang dimaksud yaitu sekelompok user yang ditargetkan untuk menggunakan hasil rancangan atau desain UX (Treder, 2013: 19-20).

\subsection{User Experience (UX) sebagai Metode Perancangan Aplikasi}

Aktivitas dasar dari alur siklus desain dengan konsep The Wheel, yaitu Analyze, Design, Prototipe, dan Evaluate yang ditunjukkan pada Gambar 2.1. Keempat aktivitas ini dapat diterapkan untuk berbagai macam perancangan, seperti: desain arsitektur, desain perangkat lunak, atau konsep desain rancangan mobil versi terbaru.

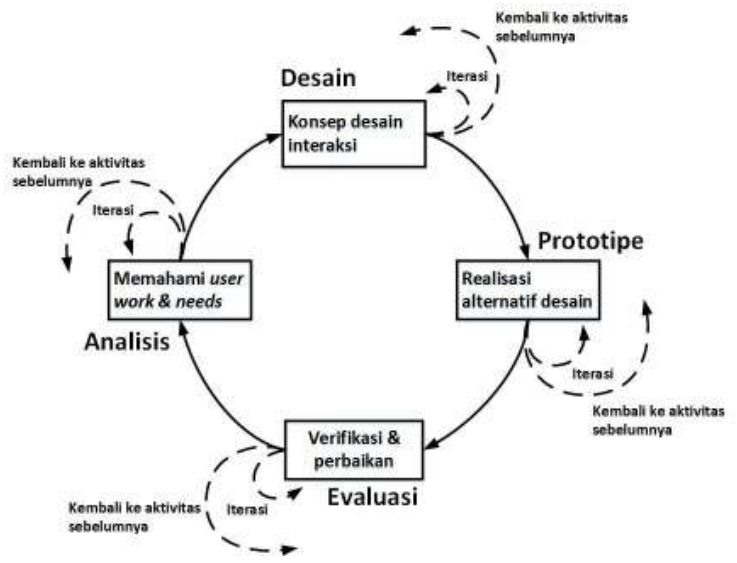

Gambar 2.1 Siklus The Wheel (Hartson dan Pyla 2012)

Setiap aktivitas dalam siklus The Wheel tidak terlepas dari status transisi waktu ketika harus meninggalkan aktivitas (leave), aktivitas yang harus dituju setelahnya (go after), aktivitas yang harus dikunjungi kembali (revisit), dan akhir dari proses transisi untuk berlanjut ke tahap produksi (stop). Tahapan siklus The Wheel dapat dilihat pada Gambar 2.1. Garis panah hitam solid menunjukkan proses yang pasti dilalui, sedangkan garis panah putus-putus menandakan proses iterasi atau kembali ke aktivitas sebelumnya yang dilakukan berdasarkan kebutuhan.

\subsubsection{Tahap Analisis \\ 2.4.1.1 Contextual Inquiry}

Contextual inquiry adalah kegiatan siklus hidup produk UX untuk mengumpulkan deskripsi rinci dari kerja praktek user dengan tujuan memahami kegiatan kerja dan pemikiran yang mendasarinya (Hartson dan Pyla, 2012: 85). Tujuan contextual inquiry adalah untuk meningkatkan kinerja user yang membangun atau meningkatkan desain sistem. Dalam penelitian yang dilakukan oleh Nadhirah (2014: 14) contextual inquiry dilakukan dengan pengumpulan data melalui wawancara, observasi, dan kuesioner online terhadap target user. Data tersebut digunakan sebagai acuan perancangan sistem yang tepat untuk mendukung aktivitas target user. Selanjutnya adalah contextual analysis.

\subsubsection{Contextual Analysis}

Contextual analysis merupakan identifikasi analisis sistematis, penyortiran, pengorganisasian, interpretasi, konsolidasi, dan komunikasi dari data aktivitas kontekstual user yang dikumpulkan pada saat contextual inquiry, dengan tujuan memahami konteks kerja sistem baru yang akan dirancang (Hartson dan Pyla, 2012: 85).

\subsubsection{Extracting Requirement}

Requirements dalam konteks UX adalah kebutuhan desain interaksi (Nadhirah, 2014: 14). Setiap note aktivitas kerja pengguna dianalisis untuk menentukan apa saja yang menjadi kebutuhan desain interaksi. Statement kebutuhan interaksi desain tersebut dikemas dalam sebuah requirements document.

\subsubsection{Tahap Desain}

\subsubsection{Design Thinking and Ideation}

Design thinking merupakan cara berpikir pada konsep desain sebuah produk untuk memberikan dampak emosional dan pengalaman pengguna secara dominan (Hartson dan Pyla, 2012: 259). Dengan kata lain, design thinking adalah sebuah pendekatan untuk menciptakan produk yang membangkitkan pengalaman pengguna, mencakup dampak emosional, estetika, dan nilai interaksi sosial.

Persona adalah karakter khusus yang dibangun untuk mewakili kebutuhan dari seluruh jajaran pengguna nyata (Garrett, 2011: 49). Dengan meletakkan wajah dan sebuah nama pada data yang terputus dari penelitian user dan segmentasi pekerjaan, persona dapat membantu untuk mengingat user selama proses perancangan.

\subsubsection{Conceptual Design}

Conceptual design adalah bagian dari desain interaksi yang berisi tema, gagasan, atau gagasan dengan tujuan mengkomunikasikan visi desain tentang sistem atau produk (Hartson dan Pyla, 2012: 305). Aktivitas pada conceptual design yaitu pembuatan storyboard. Menurut Hartson dan Pyla (2012:316) storyboard adalah urutan frame to frame yang menggambarkan interaksi antara pengguna dan sistem yang diimpikan. Storyboard membuat desain menjadi hidup dalam sebuah klip grafis dan kerangka cerita tentang bagaimana pengguna akan berinteraksi dengan sistem. Uraian naratif bisa dibuat dalam berbagai bentuk dan pada tingkat yang berbeda. 


\subsubsection{Design Production}

Design production dilakukan dengan membuat wireframe sebagai gambaran mengenai layout konten, desain interaksi pada layar, serta struktur navigasi aplikasi. Menurut Hartson dan Pyla (2012:336) sebuah wireframe adalah skematik, blueprint, atau template sebuah layar atau desain halaman web dalam sebuah desain interaksi. Hal merupakan representasi kerangka dari layar (atau halaman) tata letak dari objek interaksi seperti tab, menu, tombol, kotak dialog, tampilan, dan elemen navigasi. Fokus wireframe adalah pada konten layar dan perilaku tapi tidak pada grafis seperti font, warna, atau grafik. Wireframe menjadi awal ide desain yang nyata dikarenakan wireframe adalah dasar untuk pembuatan prototipe dengan cepat dan berulang.

\subsubsection{Tahap Prototipe}

Prototipe dibangun untuk mengimplementasikan solusi desain. Menurut Hartson dan Pyla (2012:396) berdasarkan ketelitiannya (fidelity), prototipe dibagi menjadi tiga, yaitu low-fidelity prototype, medium-fidelity prototype, dan high-fidelity prototype. Prototipe yang dikembangan pada penelitian adalah prototipe highfidelity.

High-fidelity prototype adalah representasi desain yang lebih rinci, termasuk rincian tampilan dan perilaku interaksi. High-fidelity diperlukan untuk mengevaluasi detail desain dan bagaimana pengguna dapat melihat desain secara lengkap (dalam arti realisme). High-fidelity dibuat melalui pemrograman langsung terhadap rancangan aplikasi yang telah dibuat, sehingga membutuhkan waktu dan biaya yang cukup tinggi dibandingkan dua jenis prototipe sebelumnya.

\subsubsection{Tahap Evaluasi}

Tahap evaluasi menggunakan istilah usability (daya guna) sebagai acuannya. Efek usability dapat dipahami seperti produktivitas atau kemudahan dalam penggunaan dengan mengukur indikator kinerja berbasis pengguna yang dapat diamati seperti waktu penyelesaian tugas (task completion) dan jumlah kesalahan. Kuesioner juga memberikan indikator kepuasan pengguna dari jawaban mereka atas pertanyaan yang terkait erat dengan kepuasan.

Dalam standar ISO/IEC 9126-4 (2004) mengenai quality in use matrics, menyebutkan bahwa, usability menyangkut efektivitas, efisiensi, dan kepuasan (Mifsud, 2015). Untuk mengukur tingkat efektivitas dan efisiensi dapat menggunakan task completion (penyelesaian tugas) yang diberikan kepada user. Tingkat kepuasan dapat diukur dengan menggunakan kuesioner seperti User Experience Questionnaire (UEQ).

\subsection{Dashboard}

Sebuah dashboard adalah tampilan visual dari informasi yang paling penting yang dibutuhkan untuk mencapai satu atau lebih tujuan; konsolidasi dan diatur pada satu layar sehingga informasi dapat dipantau secara sekilas (Few, 2006: 26).

\section{Metodologi}

\subsection{Diagram Alir Penelitian}

Diagram alir penelitian untuk perancangan aplikasi dashboard profil mahasiswa baru UNJ dengan konsep UX yang dilakukan dalam penelitian ini ditunjukkan pada Gambar 3.1.

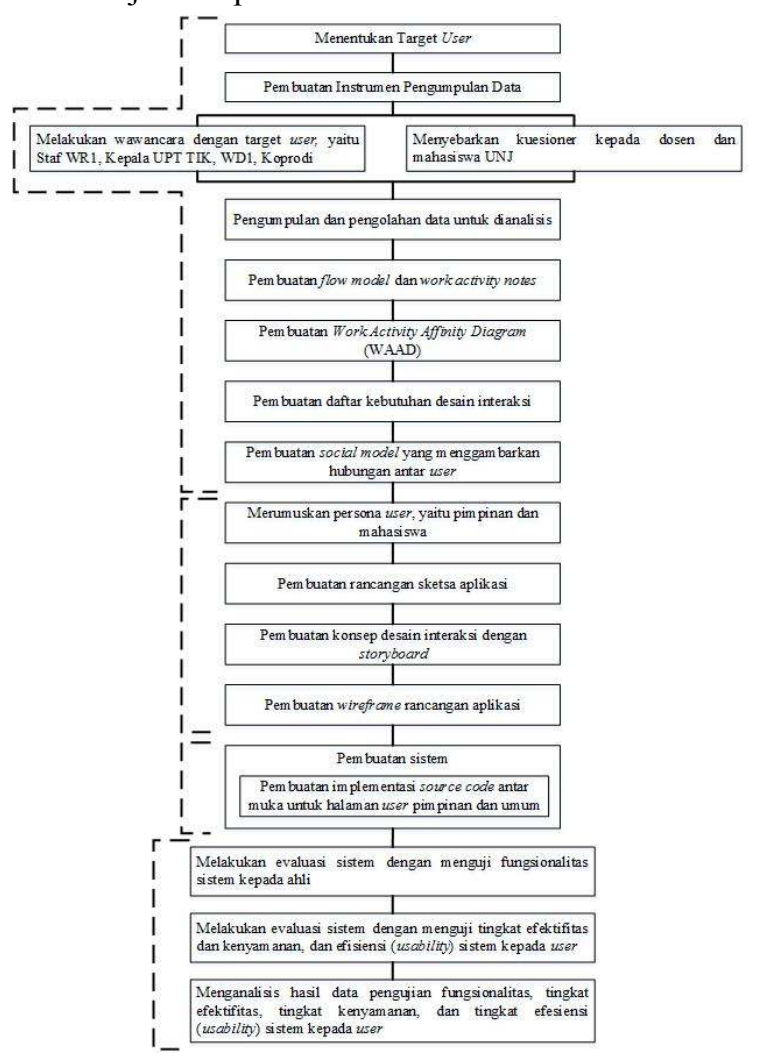

Gambar 3.1 Diagram Alir Penelitian

\subsection{Instrumen Pengumpulan Data}

Instrumen dalam penelitian digunakan untuk mengumpulkan data pada tahap analisis dan tahap evaluasi. Terdapat empat instrumen yang digunakan untuk penelitian, yaitu: (1) instrumen wawancara, (2) instrumen UEQ, (3) instrumen uji fungsional, dan (4) instrumen usability testing. Sebelum membuat instrumen diperlukan pembuatan kisi-kisi yang digunakan untuk menyusun instrumen penelitian. Kisi-kisi instrumen yang dibuat adalah instrumen UEQ dan uji fungsional. Untuk Instrumen wawancara dibuat langsung dalam pedoman wawancara.

\subsection{Teknik Analisis Data}

\subsubsection{Usability}

Menurut Al-Qutaish (2010:172) usability adalah kemampuan dari suatu produk aplikasi untuk dapat dimengerti, dipelajari, digunakan, dan menarik terhadap user ketika digunakan dalam kondisi yang sudah ditentukan.

Dalam standar ISO/IEC 9126-4 (2004) diacu dalam Mifsud (2015) mengenai quality in use 
matrics, menyebutkan bahwa, usability menyangkut efektivitas, efisiensi, dan kepuasan.

\subsubsection{Efektivitas}

Efektivitas adalah ketepatan dan kelengkapan user dalam menyelesaikan goal yang sudah ditentukan. Efektivitas dapat dikalkulasi dengan menghitung completion rate. Mengacu sebagai dasar dari usability, completion rate dapat dikalkulasi dengan menggunakan bilangan biner. Bilangan angka ' 1 ' jika responden berhasil melakukan tugas yang diberikan, dan bilangan angka ' 0 ' jika responden tidak berhasil melakukan tugas yang diberikan.

Dikarenakan kesederhanaanya, completion rate sangat mudah untuk dimengerti, oleh karena itu sebabnya kenapa perhitungan efektivitas dengan completion rate sangat populer. Efektivitas dapat direpresentasikan dalam persentase dengan menggunakan rumus berikut:

\section{Banyaknya perintah yang diselesaikan user \\ Total perintah yang diberikan user $x 100 \%$}

\subsubsection{Efisiensi}

Efisiensi adalah sumber daya yang keluarkan yang berhubungan dengan ketepatan dan kelengkapan user dalam menyelesaikan goal yang sudah ditentukan. Efisiensi diukur dari segi waktu atas perintah yang diselesaikan oleh responden, dimana waktu diukur dalam detik atau menit. Waktu yang diambil untuk menyelesaikan perintah, dapat dihitung dengan mengurangi waktu selesai dengan waktu awal mengerjakan.

\section{Task Time $=$ End Time - Start Time}

Efisiensi dapat dihitung dengan dua cara, salah satunya yaitu dengan menghitung efisiensi berdasarkan waktu.

\subsubsection{Kepuasan}

$$
\text { Efesiensi Waktu }=\frac{\sum_{j=1}^{R} \sum_{i=1}^{N} \frac{n_{i j}}{t_{i j}}}{N R}
$$

Kepuasan adalah rasa nyaman yang diterima user dalam menggunakan produk yang digunakan. Kepuasan user diukur menggunakan kuesioner kepuasan user yang sudah distandarisasi. Hal ini berfungsi untuk mengukur kesan user terhadap kemudahan terhadap produk yang digunakan. Kuesioner yang digunakan dalam mengukur kepuasan user yaitu User Experience Questionnaire (UEQ). Penilaian UEQ menggunakan skala semantik diferensial. Menurut Sugiyono (2013:97) skala semantik diferensial dikembangkan oleh Osgood. Skala ini juga digunakan mengukur sikap, hanya bentuknya tidak pilihan ganda maupun checklist, tetapi tersusun dalam satu garis kontinum yang jawaban "sangat positifnya" terletak di bagian kanan garis, dan jawaban yang "sangat negatif" terletak di bagian kiri garis, atau sebaliknya. Data yang diperoleh adalah data interval, dan biasanya skala ini digunakan untuk mengukur sikap/karakteristik tertentu yang dimiliki seseorang.

Apabila seluruh butir telah diisi, maka setiap butir diberikan poin dan dipisahkan berdasarkan skala. Setelah itu nilai mean (rata-rata) dari setiap aspek per-responden dihitung setelah poin dari masing-masing karakteristik dinilai. Rumus untuk menghitung nilai rata-rata pada masing-masing aspek yaitu:

$$
\text { Mean per Aspek }=\frac{\text { Total Bobot Poin per Aspek }}{\text { Jumlah Butir per Aspek }}
$$

Apabila nilai rata-rata per aspek dari masingmasing responden telah dihitung, maka untuk mengetahui nilai rata-rata dari seluruh responden per aspek dapat dihitung dengan:

Mean Keseluruhan per Aspek $=\frac{\text { Total Mean per Aspek }}{\text { Jumlah Responden }}$

Dari nilai rata-rata seluruh responden dapat ditentukan tingkat kepuasan user dari setiap aspek. Tabel 3.1 menunjukkan tingkat kepuasan user berdasarkan nilai dari setiap aspek.

Tabel 3.1 Tingkat Kepuasan User berdasar Nilai Setiap Aspek

\begin{tabular}{|l|c|c|c|c|c|c|}
\hline Skala & $\begin{array}{c}\text { Daya } \\
\text { Tarik }\end{array}$ & Kejelasan & Efisiensi & Ketepatan & Stimulasi & Kebaruan \\
\hline Sangat & $\geq 1,72$ & $\geq 1,64$ & $\geq 1,82$ & $\geq 1,6$ & $\geq 1,50$ & $\geq 1,34$ \\
Baik & $\geq 1,50$ & $\geq 1,31$ & $\geq 1,37$ & $\geq 1,4$ & $\geq 1,31$ & $\geq 0,96$ \\
\hline Baik & $<1,72$ & $<1,64$ & $<1,82$ & $<1,6$ & $<1,50$ & $<1,34$ \\
\hline Diatas & $\geq 1,09$ & $\geq 0,84$ & $\geq 0,90$ & $\geq 1,06$ & $\geq 1,00$ & $\geq 0,63$ \\
Rata-rata & $<1,50$ & $<1,31$ & $<1,37$ & $<1,40$ & $<1,31$ & $<0,96$ \\
\hline Dibawah & $\geq 0,65$ & $\geq 0,50$ & $\geq 0,53$ & $\geq 0,70$ & $\geq 0,52$ & $\geq 0,24$ \\
Rata-rata & $<1,09$ & $<0,84$ & $<0,90$ & $<1,06$ & $<1,00$ & $<0,63$ \\
\hline Buruk & $<0,65$ & $<0,50$ & $<0,53$ & $<0,70$ & $<0,52$ & $<0,24$ \\
\hline
\end{tabular}
Sumber: Schrepp (2011:8)

Dengan kuesioner seperti UEQ memungkinkan untuk membuat setidaknya perkiraan tentang area dimana perbaikan akan memiliki dampak tertinggi. UEQ menunjukkan suatu pola pada produk yang dievaluasi berdasarkan enam kualitas UX yang diukur. Dari pola ini dimungkinkan untuk membuat setidaknya beberapa perkiraan untuk mencari perbaikan. Untuk interpretasi dari perbandingan tolak ukur ditunjukkan oleh Tabel 3.2.

Tabel 3.2 Interpretasi Perbandingan Tolak Ukur

\begin{tabular}{|l|l|}
\hline $\begin{array}{c}\text { Perbandingan } \\
\text { Tolak Ukur }\end{array}$ & \multicolumn{1}{c|}{ Interpretasi } \\
\hline Sangat Baik & pada kisaran 10\% hasil terbaik \\
\hline Baik & $\begin{array}{l}10 \% \text { hasil dalam pengumpulan } \\
\text { data tolak ukur lebih baik dan } \\
75 \% \text { hasilnya buruk }\end{array}$ \\
\hline $\begin{array}{l}\text { Diatas Rata- } \\
\text { rata }\end{array}$ & $\begin{array}{l}\text { 25\% hasil dalam pengumpulan } \\
\text { data tolak ukur lebih baik } \\
\text { daripada hasil evaluasi produk, } \\
50 \% \text { hasilnya buruk }\end{array}$ \\
\hline $\begin{array}{l}\text { Dibawah Rata- } \\
\text { rata }\end{array}$ & $\begin{array}{l}50 \% \text { hasil dalam pengumpulan } \\
\text { data tolak ukur lebih baik }\end{array}$ \\
\hline
\end{tabular}




\begin{tabular}{|l|l|}
\hline $\begin{array}{c}\text { Perbandingan } \\
\text { Tolak Ukur }\end{array}$ & \multicolumn{1}{c|}{ Interpretasi } \\
\hline & $\begin{array}{l}\text { daripada hasil evaluasi produk, } \\
\text { 25\% hasilnya buruk }\end{array}$ \\
\hline Buruk & pada kisaran 10\% hasil terburuk \\
\hline Sumber: Schrepp (2011:7)
\end{tabular}

4. Hasil dan Analisis

\subsection{Deskripsi Hasil Penelitian}

4.1.1 Tahap Analisis

\subsubsection{Contextual Inquiry}

Pada tahap ini dilakukan wawancara langsung kepada tujuh orang pimpinan, yaitu Staf WR1, Kepala UPT TIK, Wakil Dekan Bidang Akademik FT untuk mendapatkan data pendukung awal dan sebagai bahan dalam merumuskan daftar kebutuhan desain interaksi pada contextual analysis. Wawancara terdiri dari tiga topik yaitu, aktivitas target user, kebutuhan data penerimaan mahasiswa baru UNJ, dan penggunaan teknologi informasi.

Hasil analisis wawancara pimpinan UNJ menunjukkan bahwa data penerimaan mahasiswa baru dibutuhkan oleh jajaran pimpinan antara lain sebagai bahan evaluasi akreditasi prodi, pemaparan profil prodi, profil maba bagi stakeholder UNJ, bahan pengajuan proposal hibah, dan rekapitulasi. Kendala dalam mendapatkan data maba UNJ biasanya dialami oleh Koprodi yang membutuhkan data secara langsung sebagai bahan evaluasi akreditasi. Koprodi harus melewati beberapa proses untuk mengajukan permohonan data ke BAKHUM dan menunggu hingga data itu diproses, sehingga membutuhkan waktu yang lama untuk mendapatkan data tersebut.

\subsubsection{Contextual Analysis}

Flow model dashboard profil mahasiswa baru UNJ yang menunjukkan alur informasi, hubungannya dengan pengguna, dan perangkat yang digunakan terlihat pada Gambar 4.1.

Hasil analisis wawancara terhadap tujuh orang pimpinan UNJ dari level yang berbeda mendapatkan poin-poin penting yang menjadi kebutuhan dan harapan pengguna. Setiap poin ditulis dalam sebuah note hingga terkumpul work activity notes. Setiap note tersebut diberikan nomor ID dan dikelompokkan berdasarkan kemiripannya. Struktur Work Activity Affinity Diagram (WAAD) dashboard profil mahasiswa baru UNJ dengan pemberian ID untuk setiap note ditunjukkan oleh Gambar 4.2. Kebutuhan pimpinan akan data profil mahasiswa baru terbagi menjadi tiga kategori mayor yang berada pada level 1 dan ditandai dengan warna merah. Ketiga kategori tersebut adalah kebutuhan untuk mendapatkan informasi data mahasiswa baru [A], kebutuhan untuk mengganti lingkup data [B], dan kebutuhan untuk unduh data mahasiswa baru [C]. Node-node berwarna biru menunjukkan kategori minor dan warna kuning adalah child.
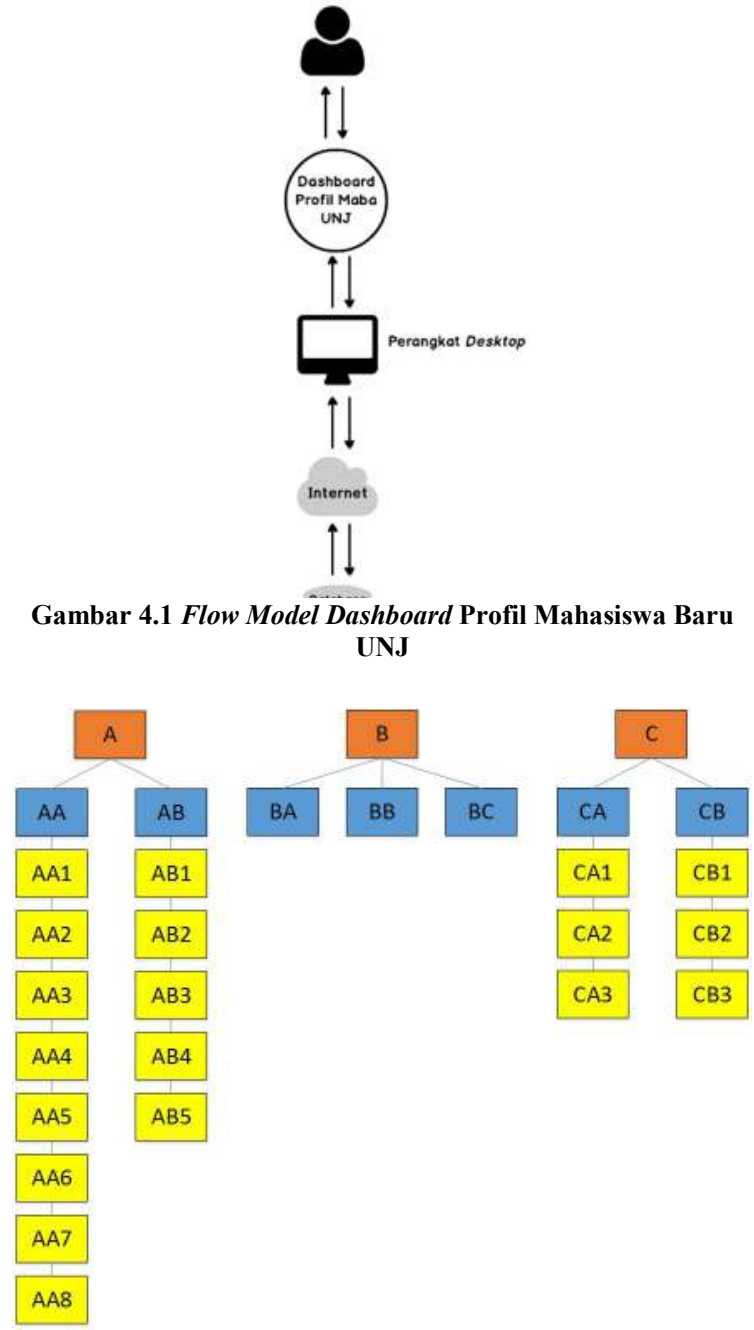

Gambar 4.2 Struktur WAAD Dashboard Profil Mahasiswa Baru UNJ

\subsubsection{Extracting Requirement}

Setiap kebutuhan pimpinan UNJ pada WAAD diekstraksi dan dianalisis kembali untuk menentukan kebutuhan desain interaksi dalam bentuk statement. Satu aktivitas kerja dapat memiliki beberapa kebutuhan desain interaksi. Kumpulan statement kebutuhan tersebut dikemas dalam sebuah requirements document

\subsubsection{Tahap Desain}

\subsubsection{Design Thinking}

Design thinking dilakukan dengan pembuatan user persona. Elemen-elemen persona dibuat berdasarkan karakteristik pengguna dari hasil wawancara dan kuesioner pada tahap analisis. Kandidat persona untuk dashboard profil mahasiswa baru UNJ adalah pimpinan dan salah satu stakeholder UNJ yaitu mahasiswa UNJ yang menjadi responden kuesioner pada tahap analisis. Tokoh persona secara spesifik dipilih berdasarkan analisis hasil kuesioner dengan prosentase terbesar untuk setiap keseluruhan respon. Contoh sser persona pimpinan UNJ ditunjukkan oleh Tabel 4.1. 
Tabel 4.1 User Persona Pimpinan UNJ

\begin{tabular}{|c|c|c|c|}
\hline \multicolumn{4}{|c|}{ gram Studi } \\
\hline & Nama & & Andrian \\
\hline & Jenis Kelamin & & Laki-laki \\
\hline & Usia & & 45 tahun \\
\hline & $\begin{array}{l}\text { Latar Belakang } \\
\text { Pendidikan }\end{array}$ & & Soshum (Manajemen) \\
\hline & Pekerjaan & & Dosen dan Ko \\
\hline \multicolumn{4}{|c|}{ Deskripsi Tentang User } \\
\hline \multicolumn{4}{|c|}{$\begin{array}{l}\text { Andrian merupakan seorang dosen sekaligus Koprodi di program studi } \\
\text { Manajemen UNJ sejak tahun } 2000 \text {. Dalam menjalankan aktivitasnya, } \\
\text { Andrian menggunakan komputer dan smartphone untuk bekerja maupun } \\
\text { berkomunikasi. Dalam satu hari pemakaian komputer bisa mencapai 3- } \\
5 \text { jam. Andrian menggunakan internet untuk mencari informasi dan } \\
\text { mengunduh data/file dalam pekerjaannya, namun Andrian lebih sering } \\
\text { menggunakan internet untuk browsing dibandingkan mengunduh data. } \\
\text { Andrian mengajar 2-3 jam dan } 3 \text { hari dalam seminggu. Selain dengan } \\
\text { kesibukan mengajar, Andrian juga harus memenuhi tanggungjawabnya } \\
\text { sebagai Koprodi seperti menangani akademik, administrasi, sampai } \\
\text { akreditasi prodi. Pada saat akan melakukan akreditasi, Andrian kesulitan } \\
\text { untuk mencari data mahasiswa baru dikarenakan proses mendapatkan } \\
\text { data yang cukup lama. Andrian juga membutuhkan data mahasiswa baru } \\
\text { untuk pemaparan profil prodi, sehingga membutuhkan sebuah aplikasi } \\
\text { yang dapat menampilkan keadaan prodinya saat ini. }\end{array}$} \\
\hline
\end{tabular}

\subsubsection{Sketching}

Sketsa pada konteks UX adalah bagian dari proses design thinking yang menggambarkan segala kemungkinan desain interaksi untuk memenuhi requirements. Contoh sketsa untuk kebutuhan halaman beranda ditunjukkan oleh Gambar 4.3.

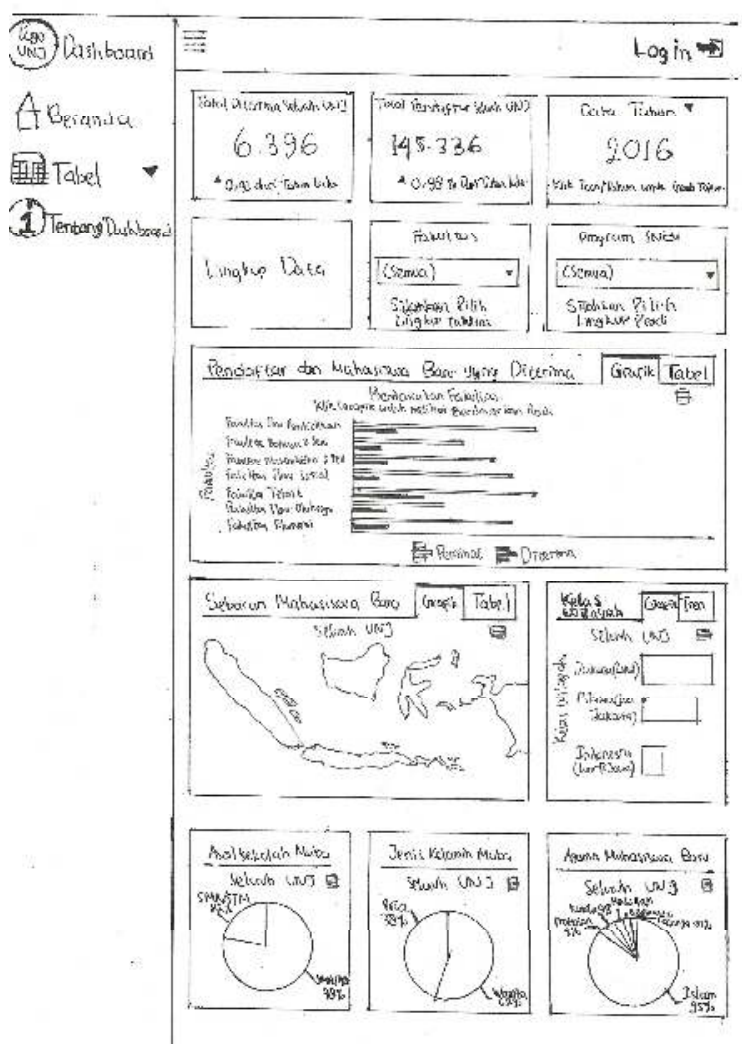

\section{Gambar 4.3 Sketsa Halaman Beranda}

Konsep interaksi desain ditunjukkan melalui frame-frame terurut yang menggambarkan hubungan pengguna dengan dashboard profil mahasiswa baru UNJ. Skenario ditujukan kepada pimpinan UNJ yang memerlukan data mahasiswa baru UNJ. Interaksi dimulai saat pengguna mulai membuka dashboard hingga mengunduh data yang diperlukan. Storyboard dashboard profil mahasiswa baru UNJ dapat dijelaskan dengan skenario yang ditunjukkan oleh Gambar 4.4.

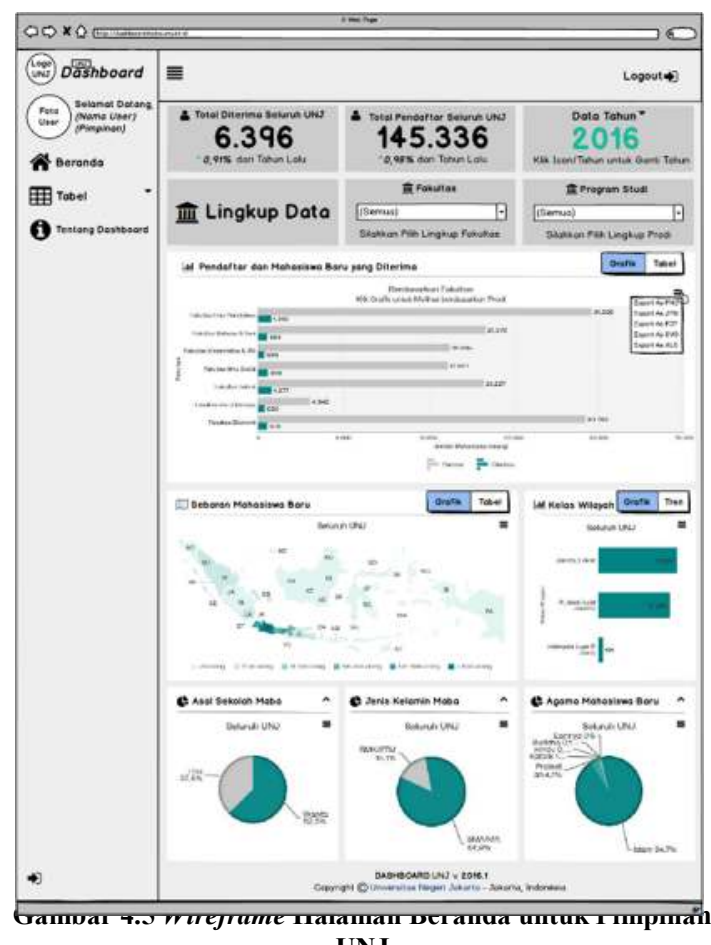

UNJ 


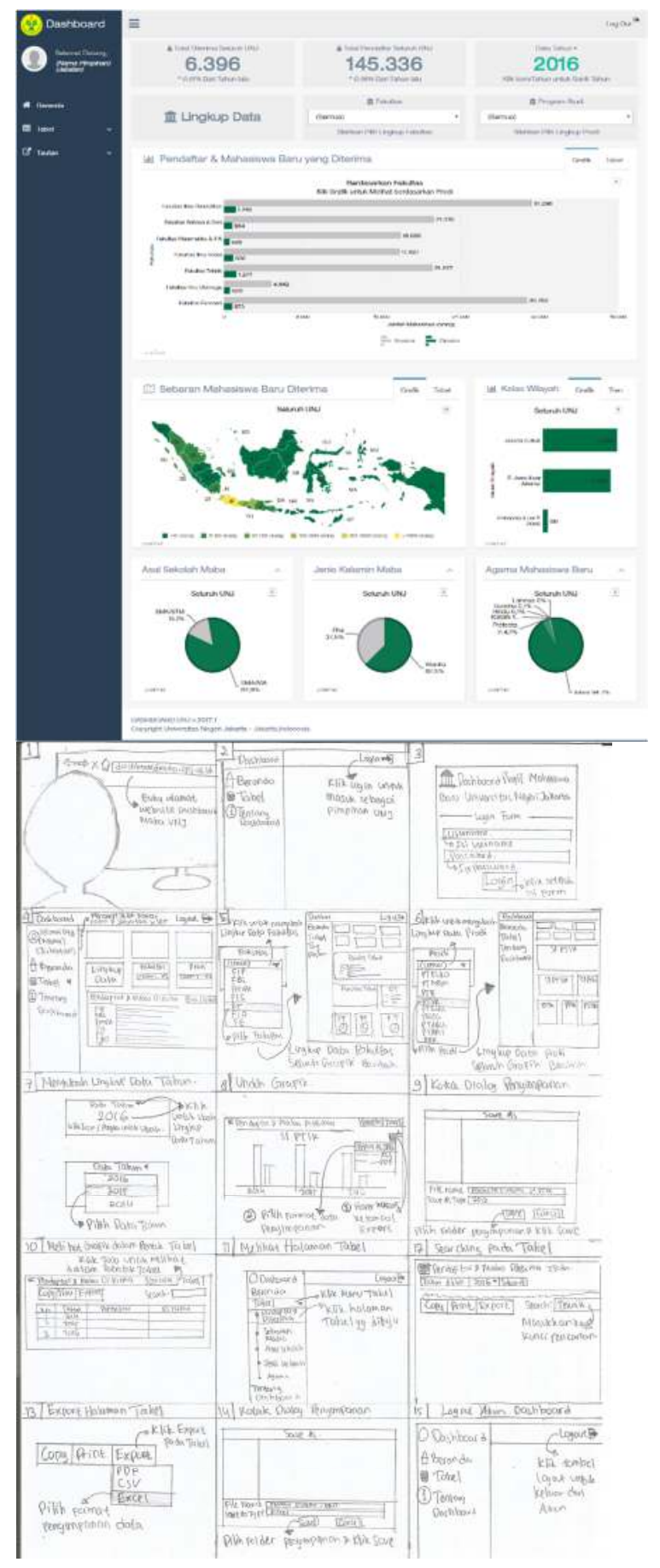

\subsubsection{Design Production}

Design production dilakukan dengan pembuatan wireframe. Wireframe dibuat sesuai dengan jumlah halaman yang dirancang, yaitu sebanyak 15 halaman. Halaman wireframe terbagi menjadi dua kategori berdasarkan level user, yaitu untuk umum (stakeholder UNJ) dan pimpinan UNJ. Perbedaan utama dari dua kategori level user adalah fitur export (unduh) hanya ada pada halaman untuk pimpinan UNJ, sedangkan halaman umum (stakeholder UNJ) tidak memiliki fitur unduh pada tabel maupun grafik. Contoh wireframe halaman beranda ditunjukkan oleh Gambar 4.5.

\subsubsection{Tahap Prototipe}

\subsubsection{Prototipe High Fidelity}

Halaman prototipe dibuat berdasarkan dua level kategori user, yaitu untuk umum (stakeholder UNJ) dan pimpinan UNJ. Sesuai dengan pembuatan wireframe, fitur unduh tidak disediakan untuk user umum, namun hanya untuk user pimpinan UNJ. Gambar 4.7 Diagram Hasil Usability Testing Segi Efektivitas Pimpinan UNJ

Contoh halaman prototipe adalah halaman beranda yang ditunjukkan oleh Gambar 4.6.

\subsection{Hasil Pengujian dan Analisis Data Penelitian}

\subsubsection{Uji Fungsional}

Uji fungsional sistem dilakukan pada hasil prototipe high fidelity dengan menggunakan kategori level user pimpinan UNJ untuk menguji seluruh fungsi yang ada pada halaman login dan enam halaman utama. Berdasarkan hasil pengujian yang dilakukan, dinyatakan bahwa produk telah perfungsi dengan baik.

\subsubsection{Usability Testing \\ 4.2.2.1 Efektivitas}

Diagram hasil usability testing pimpinan UNJ dari segi efektivitas ditunjukkan oleh Gambar 4.7. Hasil usability testing pimpinan UNJ menunjukkan bahwa dari 10 task, task 5 dan 6 memiliki nilai efektivitas $80 \%$ yang masih berada di atas rata-rata completion rate (78\%). Task 8 yang memiliki nilai $60 \%$ harus dievaluasi pada tahap analisis selanjutnya karena berada di bawah rata-rata. Diagram hasil usability testing mahasiswa dari segi efektivitas ditunjukkan oleh Gambar 4.8.

\section{Gambar 4.4 Storyboard Dashboard Profil Mahasiswa Baru} UNJ

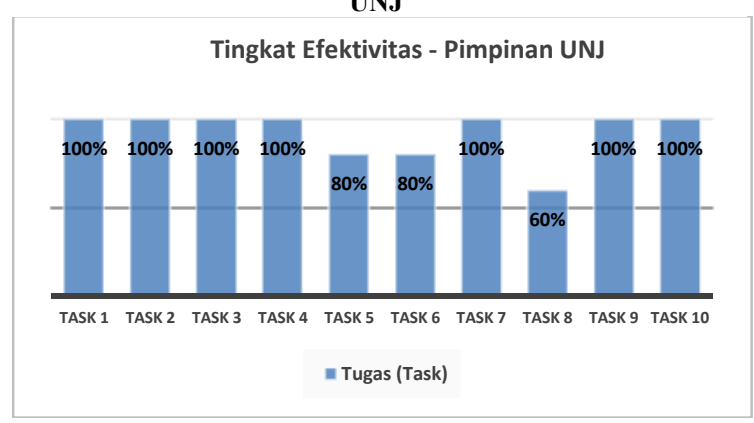




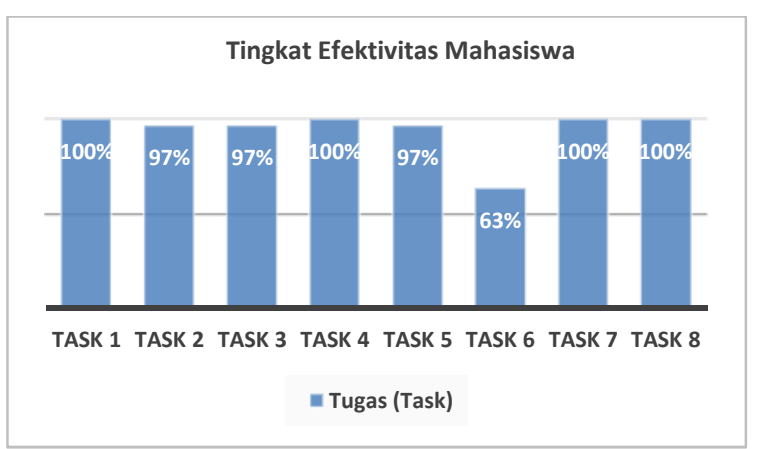

Hasil usability testing mahasiswa menunjukkan bahwa dari 10 task, task 2, 3, dan 5 memiliki nilai efektivitas $97 \%$ yang masih berada di kuartil atas rata-rata completion rate (78\%). Task 6 memiliki nilai efektivitas sebesar $63 \%$, sehingga harus dievaluasi pada tahap analisis selanjutnya karena berada di

\section{Gambar 4.10 Diagram Hasil Usability Testing Segi Efisiensi Mahasiswa}

bawah rata-rata. Setelah ditinjau kembali task 8 pada pimpinan UNJ adalah task yang sama pada task 6 mahasiswa UNJ.

\subsubsection{Efisiensi}

Efisiensi diukur dari segi waktu atas perintah yang diselesaikan oleh responden, dimana waktu diukur dalam detik atau menit. Diagram hasil usability testing pimpinan UNJ dari segi efisiensi ditunjukkan oleh Gambar 4.9.

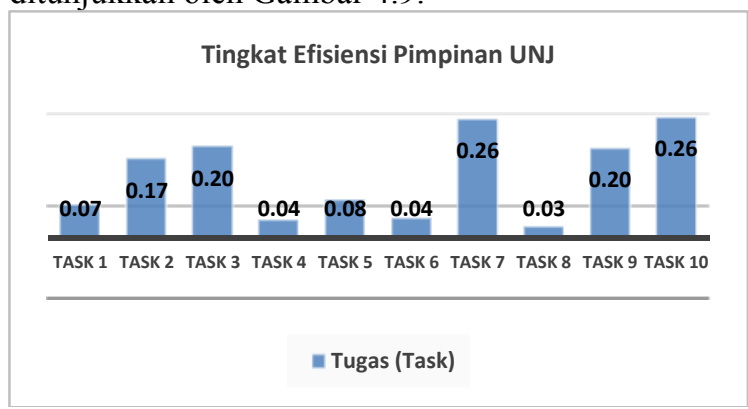

Nilai efisiensi pada Gambar 4.9 menunjukkan Gambar 4.6 Tampilan Halaman Beranda untuk Pimpinan UNJ

nilai goals/sec atau tugas/detik user pimpinan UNJ. Artinya, setiap nilai di atas adalah task yang dapat diselesaikan user per detik. Hasil usability testing

Gambar 4.10 Diagram Hasil Usability Testing Segi Kepuasan Pimpinan UNJ

pimpinan UNJ menunjukkan bahwa dari 10 task, 3 task memiliki nilai efisiensi yang paling kecil di antara 7 task lainnya. Diagram hasil usability testing pimpinan UNJ dari segi efisiensi ditunjukkan oleh Gambar 4.10.

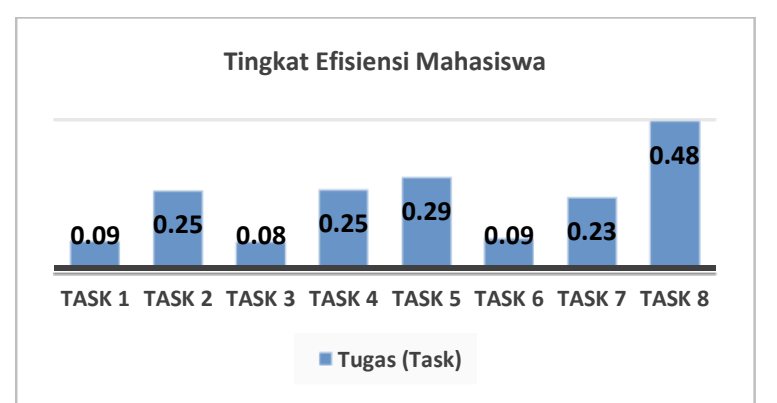

Hasil usability testing mahasiswa menunjukkan bahwa dari 8 task, 3 task memiliki nilai efisiensi yang paling kecil di antara 3 task lainnya, yaitu task 1, 3, dan 6, sehingga harus dievaluasi pada tahap selanjutnya.

\subsubsection{Kepuasan}

Kepuasan user diukur menggunakan kuesioner kepuasan user yang sudah distandarisasi. Diagram hasil usability testing pimpinan UNJ untuk segi kepuasan pada Gambar 4.10 menunjukkan bahwa seluruh aspek, yaitu daya tarik, kejelasan, efisiensi, ketepatan, stimulasi, dan kebaruan memiliki penilaian sangat baik. Berdasarkan interpretasi perbandingan tolak ukur pada Tabel 3.2, penilaian sangat baik menunjukkan bahwa aspek berada pada kisaran $10 \%$ terbaik.

Gambar 4.8 Diagram Hasil Usability Testing Segi Efektivitas Pimpinan UNJ

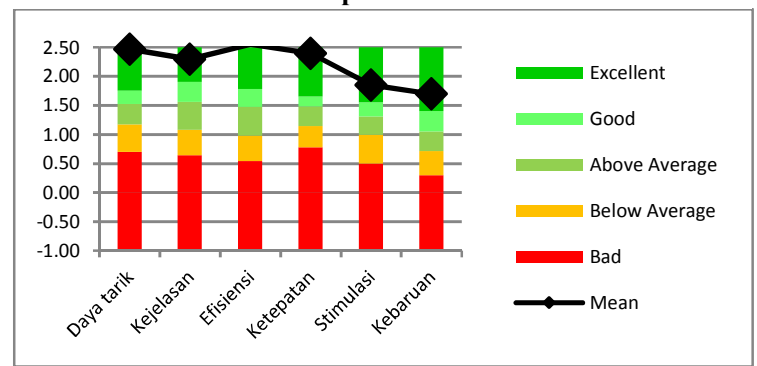

Diagram hasil usability testing mahasiswa untuk segi kepuasan pada Gambar 4.11 menunjukkan bahwa aspek data tarik, kejelasan, efisiensi, stimulasi, kebaruan memiliki penilaian sangat baik, sedangkan aspek ketepatan memiliki penilaian baik. Berdasarkan interpretasi perbandingan tolak ukur pada Tabel 3.2, penilaian sangat baik menunjukkan bahwa aspek berada pada kisaran 10\% terbaik, sedangkan penilaian baik menunjukkan bahwa aspek berada dibawah kisaran $10 \%$ hasil tolak ukur terbaik. 


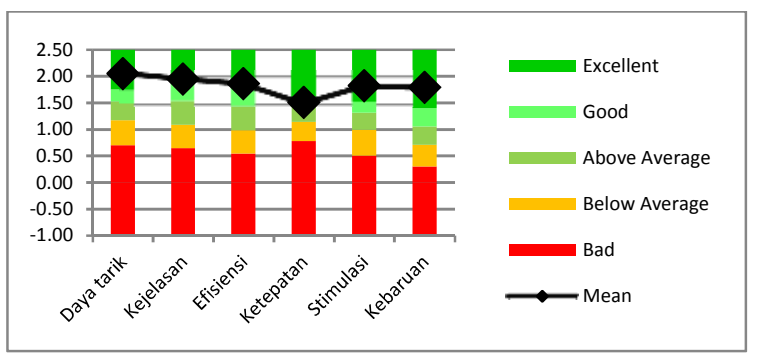

\subsection{Aplikasi Hasil Penelitian}

Hasil penelitian dapat digunakan sebagai acuan dalam pengembangan dashboard tahap selanjutnya dengan menggunakan data yang telah disahkan oleh pimpinan UNJ untuk menyampaikan informasi profil maba UNJ ke stakeholder UNJ dan sebagai bahan evaluasi akreditasi.

\section{Kesimpulan dan Saran \\ 5.1 Kesimpulan}

Proses perancangan Dashboard Profil Mahasiswa Baru Universitas Negeri dilakukan dengan metode konsep perancangan User Experience (UX). Metode perancangan yang digunakan adalah siklus The Wheel yang terdiri dari empat tahap. Tahap pertama adalah tahap analisis yang terdiri dari contextual inquiry, contextual analysis, dan extracting requirement. Tahap kedua adalah tahap desain yang terdiri dari design thinking, sketching, conceptual design, dan design production. Tahap ketiga adalah tahap prototipe dengan pembuatan prototipe high fidelity. Tahap keempat adalah tahap evaluasi yang terdiri dari uji fungsional dan usability testing.

Dashboard profil mahasiswa baru UNJ yang dikembangkan telah diuji dengan beberapa jenis pengujian, seperti pengujian fungsional dan usability. Berdasarkan hasil pengujian, dinyatakan bahwa dashboard secara fungsional sudah berjalan dengan baik. Pengujian usability dilakukan terhadap dua ketegori user, yaitu pimpinan UNJ dan stakeholder UNJ (mahasiswa). Usability testing menyangkut tiga hal, yaitu efektivitas, efisiensi, dan kepuasan. Hasil usability testing menunjukkan bahwa dari segi efektivitas sebagian besar task berada diatas rata-rata completion rate, dari segi efisiensi memiliki waktu pemakaian produk yang cukup baik pada sebagian besar task dan dari segi kepuasan menunjukkan hasil baik dan sangat baik.

\subsection{Saran}

Penelitian dan pengembangan lebih lanjut disarankan untuk melakukan poin-poin berikut:
1. Melakukan Penelitian dengan Konsep Perancangan Perangkat Lunak selain User Experience (UX).

2. Memperbanyak jumlah sample pada proses uji coba produk.
Al-Qutaish, R. E. (2010), Quality models in software engineering literature: an analytical and comparative study, Journal of America Science, Vol.6, pp. 166-175.

Doody, S. (2016), Free Guide: 35 Questions for User Research Interviews, [dokumen], http://s3.amazonaws.com/convertkit/landing_p ages/incentives/000/202/798/original/UserRese

Gambar 4.11 Diagram Hasil Usability Testing Segi Kepuasan Mahasiswa

arch_Guide_By_Sarah_Doody.01.pdf?1493315 874, Diakses 17 April 2017.

Few, S. (2006), Information Dashboard Design The Effective Visual Communication of Data, Gravenstein Highway North Sebastopol, O'Reilly Media.

Hartson, R., \& Pyla, P. (2012), The UX Book Process and Guidelines for Ensuring a Quality User Experience, Waltham, Morgan Kaufmann.

Mifsud, J. (2015), Usability Metrics - A Guide To Quantify The Usability Of Any System, [terhubung berkala]. http://usabilitygeek.com/usability-metrics-aguide-to-quantify-system-usability/, Diakses 25 April 2017.

Muchsin, A. K. (2016), Penerapan Kombinasi Fuzzy C-Means dan ELECTRE (Ellimination and Choice Translation Reality) Untuk Sistem Pendukung Keputusan Penentuan Besar Uang Kuliah Tunggal Mahasiswa Baru [tesis], Jakarta, Program Pasca Sarjana Universitas Udayana.

Muslih, M. T., \& Purnama, B. E. (2013), Pengembangan aplikasi sms gateway untuk informasi pendaftaran peserta didik baru di SMAN 1 jepara, Indonesian Jurnal on Networking and Security (IJNS), Vol.2, pp. 5055.

Nadhirah, A. S. (2014), Perancangan Mobile User Experience Aplikasi Visit Puncak untuk Perkiraan Kunjungan Wisatawan Kawasan Puncak Kabupaten Bogor [skripsi], Bogor, Fakultas Matematika dan Ilmu Pengetahuan Alam, Institut Pertanian Bogor.

Rasmussen, N., Chen, C. Y., \& Bansal, M. (2010), Business Dashboards: Mengendalikan Bisnis Melalui Layar Monitor, Jakarta, PPM.

Schrepp, M., Hinderks, A., \& Thomaschewski, J. (2011), Applying the User Experience Questionnaire (UEQ) in different evaluation scenarios, Berlin, Springer-Verlag.

Sugiyono. (2013), Metode Penelitian Kuantitatif, Kualitatif, dan $R \& D$, Bandung, Alfabeta.

Supranto, J. (2000) Statistik Teori dan Aplikasi, Jakarta, Erlangga.

\section{Daftar Pustaka:}

